\title{
Visions of Europe in Crisis: Strategic narratives and their alternatives in Russian state and independent media coverage of the 2015-16 'Refugee Crisis'
}

Madeleine Tiratsoo, University College London

\section{Abstract}

This article examines the use of state-controlled media in Russia to promote a 'strategic narrative', adopting the conceptual framework proposed by Miskimmon, O'Loughlin and Roselle (2013), and assesses the potential role of independent media in challenging these narratives. The 2015-16 'refugee crisis' in Europe is taken as a case study to investigate how a strategic narrative was developed on state-controlled media at a time of deteriorating relations between Russia and the EU and the alternative offered by independent media. Based on analysis of 609 news reports on the 'refugee crisis' from state-controlled broadcaster Channel One and 181 news pieces from the independent web-based outlet TV Rain, this article argues that reporting on Channel One developed a vision of Europe as divided, dangerous and dysfunctional. It further finds that TV Rain was able to challenge this narrative in multiple ways and proposes a novel typology describing how independent media respond to state-controlled outlets in conditions where media freedom is compromised.

\section{Keywords}

Russia, grounded theory, refugees, strategic narratives, independent media, statecontrolled media 


\section{Introduction}

The narratives states tell about themselves and their neighbours can create shared meaning, identify who "we" are and who "we" are not, and define the type of world order the state wishes to see. These narratives, whether disseminated by political actors or state mass media, can pursue strategic aims: to influence the development of certain policies, to articulate an understanding of the international order, or to determine a shared identity. Recently scholars have turned their attention to the ways in which these strategic narratives are formed and projected, as indicative of states' priorities, values and objectives; and attempted to assess the extent to which these narratives are accepted or rejected by their audience. This article builds on the developing literature on strategic narratives by examining the use of such narratives in the Russian media.

Relations between Russia and the West deteriorated sharply following the annexation of Crimea in 2014, and this was reflected in a markedly more negative portrayal of the West in Russian state-controlled media. ${ }^{1}$ This paper investigates the reporting associated with a particular phenomenon: the 2015-16 European 'refugee crisis'2 as a case study for the deployment of strategic narrative in the Russian media. Furthermore, the paper examines how independent media can respond to dominant narratives, in conditions where most media are subject to state pressure.

This study examines the period from 1 April 2015 to 1 April 2016, covering the most severe phase of the refugee crisis in terms of both real events and intensity of media coverage. Russian domestic media devoted considerable coverage to these events. ${ }^{3}$ This study focuses on news broadcasts from Channel One, the most widely watched channel among Russian audiences, and reporting from TV Rain, the most prominent independent television network in Russia.

The research finds that across a year of reporting on the crisis, Channel One developed a strategic narrative that cast Europe as divided, dangerous, and dysfunctional. While some of the tropes observed on Channel One concerning migrants and refugees have been found more widely in European and international media, the Russian state-controlled media also linked the crisis to a strategic understanding of the world order that had much in common with that expressed by Russian state officials. TV Rain, as might be expected, reported events somewhat differently and used a variety of tactics to subvert and challenge the

\footnotetext{
1 Oleksiy Makukhin, Liubov Tsybulska, and Ruslan Kavatsiuk, 'How Russian media foments hostility toward the West', Hybrid Warfare Analytical Group, September $2018<$ https://uacrisis.org/wpcontent/uploads/2018/02/TV-II-n.pdf>.

2 Some have disputed that this should be designated a 'crisis', arguing that the arrival of one million people to a continent of over 500 million should not be considered as such (Baerwaldt, 2018; Trilling, 2019). This study uses the term 'refugee crisis' throughout to refer to the phenomenon in question not because the researcher concurs that this was a true crisis, but because it was described as such by the majority of media outlets covering the events, both in Russia and internationally. The use of scare quotes or tedious repetition of 'so-called' is therefore avoided.

3 Braghiroli, Stefano and Makarychev, Andrey, 'Redefining Europe: Russia and the 2015 Refugee Crisis', Geopolitics, 23.4 (2018), 823-848.
} 
dominant narrative. Indeed, this study suggests that TV Rain functions as a watchdog to state-controlled media.

The structure of this paper is as follows. In the first section, the strategic narrative framework is presented and the existing literature framing this study is reviewed. The second section provides background on the contemporary Russian media landscape and explains the role of media in projecting strategic narratives. In the third section, the study's methodology is explained, and the rationale of data collection presented. The fourth presents findings from analysis of 609 Channel One news reports, and 181 TV Rain pieces, describing the major themes identified in Channel One reports and the reaction to their narrative found on TV Rain. The final section offers my conclusion as to the political intent behind state-controlled media's strategic narrative, and the way that independent media respond to and challenge that narrative. 


\section{Strategic narratives and how they are communicated: theoretical framework}

What stories do states tell about themselves and their neighbours? What identity do they seek to promote, and how do they communicate it? This paper seeks to address these questions using the strategic narrative framework proposed by Miskimmon, O'Loughlin and Roselle for analysing states' messaging. ${ }^{4}$ Strategic narratives, they write,

are a means by which political actors attempt to construct a shared meaning of the past, present, and future of international politics to shape the behaviour of domestic and international actors. ${ }^{5}$

Strategic narratives constructed by political actors thus seek to promote their values and objectives for the international order by shaping expectations and determining the limits of acceptable discourse. Strategic narratives can be addressed to both domestic and international audiences. The authors identify three main forms of strategic narrative:

System narratives which articulate an understanding of the international order (e.g., the Cold War; the War on Terror);

Identity narratives which communicate a political actor, organisation or state's values, objectives, and motivation (e.g., the Free World);

Policy narratives which set out why a specific policy is necessary and how to achieve it (e.g., conflict resolution narratives).

The most effective strategic narratives combine all three, while contradictions between these would undermine the overall impact of a narrative.

Miskimmon et al. propose three stages in communicating a strategic narrative: formation, in which political actors and institutions achieve consensus on strategic goals and construct the narrative; projection, in which narratives are disseminated (and contested) in the media environment, both domestically and internationally; and reception, which assesses the narrative's reach, and its interpretation by the audience. This study focuses on the projection stage, examining how narrative is constructed, promoted and contested in a given media environment. As such it aims to illuminate the mechanisms by which strategic narratives are communicated to the domestic public, and the extent to which the media ecology can provide alternative narratives in response.

Being a relatively recent conceptualisation, the literature employing the strategic narrative framework is not extensive. Nonetheless, several scholars have successfully used it to

\footnotetext{
${ }^{4}$ Alister Miskimmon, Ben O'Loughlin, and Laura Roselle, Strategic narratives: communication power and the new world order (New York, London: Routledge, 2013).

${ }^{5}$ Forging the world: strategic narratives and international relations, ed. by Miskimmon, Alister, O'Loughlin, Ben and Roselle, Laura (Ann Arbor: University of Michigan Press, 2017), p. 6.
} 
analyse Russian state narratives. Roselle studied Russia's great power identity in the postSoviet period, focussing on narratives surrounding the Chechen Wars to demonstrate the difficulty of changing a system narrative. ${ }^{6}$ Szostek finds strategic narrative the most appropriate concept to explore the anti-Westernism of the Russian state at the time of the annexation of Crimea. ${ }^{7}$ She distinguishes between narratives about the West, primarily the USA, and about Europe, finding that while attitudes towards the former were hostile, the latter was seen as wayward but redeemable, with deep cultural connections to Russia. Oates and Steiner examine how recent discourse around "Russophobia" fits into a metanarrative of "the West against Russia", and chart the appearance of this narrative both in the discourse of public officials, and on Russian media. ${ }^{8}$ Hinck, Kluver and Cooley emphasise Russian news broadcasts as the medium through which the Kremlin's worldview is communicated, analysing over 1000 news segments to identify strategic narratives on BRICS, the SCO, and NATO. ${ }^{9}$ In their 2019 book Global Media and Strategic Narratives of Contested Democracy, the same authors put Russian media in context by comparing their narrative on the 2016 US Presidential election with that of media in China and the Middle East. ${ }^{10}$

For several decades, the question of states' promotional messaging has been dominated by the concept of 'soft power' as conceptualised by Joseph Nye: the resources besides coercion which states use to influence other actors in the international environment, such as cultural products, student exchange programmes, or symbolic events. ${ }^{11}$ The strategic narrative framework outlined by Miskimmon et al. addresses several of the gaps found in this theory and thus is more appropriate for research into contemporary Russian media. ${ }^{12}$ Soft power focuses solely on a nation's image among the international audience, thus failing to incorporate the domestic dimension of state messaging. ${ }^{13}$ Similarly 'sharp power', a concept more recently coined to describe attempts to influence foreign audiences through manipulation and distortion of information, focusses on the impact a state may have on audiences in targeted countries abroad. ${ }^{14}$ As well as building influence with international actors, the state directs messaging at its own citizens. This may serve to

\footnotetext{
${ }^{6}$ Laura Roselle, 'Strategic Narratives and Great Power Identity', in Forging the world: strategic narratives and international relations ed. by Miskimmon, Alister, O'Loughlin, Ben and Roselle, Laura (Ann Arbor: University of Michigan Press, 2017), pp. 56-84.

7 Joanna Szostek, 'Defence and Promotion of Desired State Identity in Russia's Strategic Narrative', Geopolitics, 22.3 (2017), pp. 571-593.

8 Sarah Oates and Sean Steiner, 'Projecting Power: Understanding Russian Strategic Narrative', Russian Analytical Digest, 229 (2018), pp. 2-5.

9 Robert Hinck, Randolph Kluver, and Skye Cooley, 'Russia re-envisions the world: strategic narratives in Russian broadcast and news media during 2015', Russian Journal of Communication, 10.1 (2018), pp. 21-37. 10 Robert Hinck, Skye Cooley, and Randolph Kluver, Global Media and Strategic Narratives of Contested Democracy: Chinese, Russian, and Arabic Media Narratives of the US Presidential Election, (London: Routledge, 2019).

11 Joseph Nye, Bound to Lead: The Changing Nature of American Power (New York: Basic Books, 1990); Soft Power: The Means to Success in World Politics (New York: PublicAffairs, 2004).

12 Miskimmon et al., 2013.

13 Szostek, 2017.

${ }^{14}$ Christopher Walker, Jessica Ludwig, Juan Pablo Cardenal, Jacek Kucharczyk, Grigorij Meseznikov, and Gabriela Pleschova, 'Sharp Power: Rising Authoritarian Influence', National Endowment for Democracy, 5 December 2017, https://www.ned.org/sharp-power-rising-authoritarian-influence-forum-report/>
} 
promote national cohesion, or to consolidate public support for the ruling elite. ${ }^{15}$ The domestic focus included in the strategic narrative framework is particularly appropriate in the case of Russia, given the importance the Kremlin places on controlling its domestic perception. ${ }^{16}$ Strategic narratives also incorporate the negatively directed aspects of state messaging: rather than merely promoting a positive image of the "home state", they may aim to establish an unfavourable view of a competitor state.

Oates and Steiner also note the utility of analysing strategic narratives in contrast to approaches which aim to identify disinformation. Rather than cataloguing individual examples of false or selective reporting, which may become overwhelming, identifying the overarching narrative may be a more productive and efficient method of analysis.

This study contributes to the literature on strategic narratives by examining the case study of the European refugee crisis, as seen in Russian media. It focuses on the projection of strategic narrative on state-controlled television. By comparing this narrative with independent media coverage, this study also asks the previously unresearched question: how do independent outlets react to strategic narratives found in dominant, statecontrolled media? Do they accept and co-opt such narratives as hegemonic? Do they ignore them entirely? Or do they seek to challenge them? There is very little research comparing state-controlled and independent media, and to the best of this researcher's knowledge this is the first study employing Miskimmon et al.'s framework to do so.

\footnotetext{
15 Stephen Hutchings and Vera Tolz, Nation, ethnicity and race on Russian television: mediating post- Soviet difference, (London: Routledge, 2015).

16 Szostek, 2017, p. 586.
} 


\section{Background}

\section{Strategic narratives and the media}

The single greatest factor in how political actors and states in the modern world project their chosen strategic narrative is the communicative power of the media. For communication theorist Manuel Castells, communication is the fundamental process through which consensus is reached and norms constructed, for any society that does not rely wholly on coercion. According to the framework laid out in Castells' Communication Power, 'Power relies on the control of communication, as counterpower depends on breaking through such control'. ${ }^{17}$ Achieving any political goal - including the projection of a strategic narrative - relies on the construction of shared meaning, which at the societal level takes place primarily through media. In authoritarian regimes - including Russia, in Castells' assessment - media can therefore be 'a potent form of domination' in that it defines the power relationships on which politics is based. ${ }^{18}$

The media is also dependent on the political system to operate. Castells acknowledges that there is always some degree of government control over the media, but this varies greatly between regimes. He identifies four main strategies through which the government can influence media: by exercising political control over public media; by pressuring private media owners; by legislating to enable government control of communication; and by targeted intimidation of journalists. ${ }^{19}$ All four strategies have at times been deployed in Russia. Although control over the media reflects the balance of power in society, Castells also recognises the potential of communication networks to effect change. Any social movement must entail 'reprogramming' the cultural codes and values of communication. ${ }^{20}$ Thus even in challenging a hegemonic media narrative, alternative media may play the deciding role.

\section{Russia's Media Landscape}

The contemporary Russian media landscape is overwhelmingly dominated by statecontrolled television. This study chooses to focus on television precisely because it is the most influential form of media in Russia, with by far the greatest penetration among the population; television access is available to $97.6 \%$ of the population. ${ }^{21}$ When asked where they receive most of their news, the vast majority of Russian citizens answer television, with over $91 \%$ watching news on television at least once a week in the period studied here. ${ }^{22}$ By contrast, $46 \%$ accessed news online with this frequency, 36\% read newspapers, and 34\% listened to news on the radio. Moreover, surveys over many years have shown that

\footnotetext{
${ }^{17}$ Castells, Manuel, Communication power (Oxford, New York: Oxford University Press, 2009), p. 22.

18 Ibid, p. 244.

19 Ibid, p. 330.

20 Ibid, p. 372.

${ }^{21}$ Vera Zakem, Paul Saunders, Umida Hashimova, and Kathleen Hammerberg, Mapping Russian Media Network: Media's Role in Russian Foreign Policy and Decision-making', CNA, January 2018 <https://www.cna.org/cna files/pdf/DRM-2017-U-015367-3Rev.pdf>.

22 Denis Volkov and Stepan Goncharov, 'Rossiiskii medialandshaft: osnovnye tendentsii ispol'zovaniia SMI 2017', Levada-tsentr, 22 August 2017 <https://www.levada.ru/2017/08/22/16440>.
} 
television is the most trusted source, while television news about foreign policy is more likely to be considered truthful than economic news. ${ }^{23}$

This study focuses on media coverage from 2015-16, a period in which television was undisputed ly the dominant media format, although in the years since there has been some decline in viewership. Surveys show that the proportion of Russians who cited television as their most frequent news source declined from 90\% in 2013, to 74\% in 2020. ${ }^{24}$ Although television remains by far the most trusted source of news across the population as a whole, trust is declining primarily in under-35s. ${ }^{25}$ As media use is highly differentiated across generations, many anticipate that the media landscape will shift as larger proportions of the population turn to the internet for news.

News is most widely watched on Channel One (Pervyi kanal), Russia 1 (Rossiia 1) and NTV in that order. ${ }^{26}$ Channel One was selected as the object of this study as it has the largest audience. It is aimed at both a domestic audience and Russian-speaking populations abroad. The Russian state owns 51\% of the channel with the remainder divided between National Media Group and Roman Abramovich, an oligarch close to the Kremlin. ${ }^{27}$ In practice, most observers consider it to be under state control, as they do Rossiia 1 and NTV. ${ }^{28}$ Between them, these channels account for $87 \%$ of viewership. ${ }^{29}$ There are no channels in standard broadcasting packages which have a reputation for political independence.

Studies of Russian state-controlled media indicate that information is manipulated in order to reduce the likelihood of public dissatisfaction with the regime, and that these media are consistently flattering to the Kremlin..$^{30}$ This is achieved both by encouraging selfcensorship, and through direct interventions from the Presidential Administration. ${ }^{31}$ Selfcensorship is encouraged with both positive incentives - access to sources, for example and selectively applied punishments, such as withdrawing state subsidies, or the targeted

\footnotetext{
23 'Doverie SMI i tsenzura', Levada-tsentr, 18 November 2016 <https://www.levada.ru/2016/11/18/doveriesmi-i-tsenzura>; Stepan Goncharov, 'The Whys and Wherefores of Russians' Trust in their Media', Riddle, 27 June 2019 <https://www.ridl.io/en/the-whys-and-wherefores-of-russians-trust-in-their-media>. 24 Denis Volkov and Stepan Goncharov, 'Rossiiskii medialandshaft 2020', Levada-tsentr, 28 April 2020 https://www.levada.ru/2020/04/28/rossijskij-medialandshaft-2020.

$25 \mathrm{Ibid}$; and Denis Volkov and Stepan Goncharov, 'Rossiiskii medialandshaft 2019: televidenie, pressa, internet i sotsial'nye seti', Levada-tsentr, 1 August 2019<https://www.levada.ru/2019/08/01/21088>.

26 Zakem et al, 2018.

27 Tomila Lankina and Kohei Watanabe, "Russian Spring' or 'Spring Betrayal'? The Media as a Mirror of Putin's Evolving Strategy in Ukraine', Europe-Asia Studies, 69.10 (2017), pp. 1526-1556.

28 Hutchings and Tolz, 2015.

29 Zakem et al, 2018.

${ }^{30}$ Anastasia Kazun, 'Framing sanctions in the Russian media: the rally effect and Putin's enduring popularity’, Demokratizatsiya, 24.3 (2016), pp. 327-50; Makukhin et al., 2018; Arturas Rozenas and Denis Stukal, 'How Autocrats Manipulate Economic News: Evidence from Russia’s State-Controlled Television', The Journal of Politics, 81.3 (2019), pp. 982-96.

31 Zakem et al., 2018; Natalia Roudakova, Losing Pravda: Ethics and the Press in Post-truth Russia (Cambridge: Cambridge University Press, 2017); Elisabeth Schimpfossl and Ilya Yablokov, 'Coercion or Conformism? Censorship and Self-Censorship among Russian Media Personalities and Reporters in the 2010s', Demokratizatsiya: The Journal of Post-Soviet Democratization, 22.2 (2014), pp. 295-311.
} 
enforcement of legal regulations. ${ }^{32}$ Interviews with former employees from state television channels indicate that senior editors meet weekly with Kremlin officials, and are given detailed instructions for covering sensitive issues, at times specifying individual word choices. $^{33}$

There remains some space for independent media in Russia, and despite tightening control in Putin's third term, critical reporting of Russian politics continues. Lipman argues, however, that independent media are tolerated precisely because of their irrelevance: their reach is insignificant compared to that of state-controlled media and they are therefore permitted to act as a 'pressure valve' to relieve dissatisfaction with the authorities. ${ }^{34}$

Founded in 2010, TV Rain built its reputation on covering events which other channels ignored, particularly following coverage of the 2011-12 protests which were not reported elsewhere. ${ }^{35}$ Although its penetration was dwarfed by Channel One and Rossiia 1 , by late 2013, it had found a sizeable audience of around 20 million viewers. ${ }^{36}$ It had an independent editorial line and offered the most balanced political perspective on Russian television, hosting everyone from then-President Medvedev to leading opposition figures like Alexei Navalny. ${ }^{37}$ However, it fell victim to the state's ability to put pressure on media companies. After posting a controversial poll on its website in January 2014, TV Rain was dropped by the largest cable and satellite providers, reducing its viewership sevenfold, and lost most advertising revenues. ${ }^{38}$ Although the providers cited commercial reasons, reports suggested these companies withdrew their support under pressure from the Kremlin and the poll was merely a pretext. ${ }^{39}$ The channel was forced to switch to an alternative funding model and became an online-only subscription service. This enabled it to survive, but its audience was greatly reduced. In 2015, it had approximately 60,000 subscribers. ${ }^{40}$ This limited reach should be contextualised against the vastly greater audience of the statecontrolled channels. Channel One's 9pm news, for example (one of the programmes studied in this research), generally surpasses 2.5 million viewers. ${ }^{41}$

Media organisations are responsive to the needs of their specific audiences, and given the difference in viewership, it should be noted that the incentives for TV Rain are very different

\footnotetext{
32 Sarah Oates, 'The neo-Soviet model of the media', Europe-Asia studies, 59.8 (2007), pp. 1279-1297.

33 Dmitry Sidorov, 'How Russian TV propaganda is made', Open Democracy, 25 August 2015

<https://www.opendemocracy.net/en/odr/how-russian-tv-propaganda-is-made>

34 Maria Lipman, 'Independent Media Live on in Putin's Russia', Russian Analytical Digest, 197 (2017), pp. 2-5.

35 Samuel Greene and Graeme Robertson, Putin v. the people: the perilous politics of a divided Russia (New

Haven: Yale University Press, 2019), p. 40.

36 Ibid., p.96.

37 Ibid., p. 40, 96; Shaun Walker, 'TV Rain: Inside Russia's only independent TV channel', Guardian, 9 June 2015 <https://www.theguardian.com/cities/2015/jun/09/tv-rain-russia-only-independent-televisionchannels.

38 'Ne slyshali pro «Dozhd'»', Levada-tsentr, 28 February $2014<$ https://www.levada.ru/2014/02/28/neslyshali-pro-dozhd>

39 Greene and Robertson, pp. 96-7.

40 Walker, 2015.

41 Data obtained from Mediascope media research company (Online). Available from: https://mediascope.net/data/?FILTER TYPE=tv [Accessed 18 August 2020].
} 
to those for Channel One or Russia $1 .{ }^{42}$ While the latter are 'broadcasters' in the most conventional sense, in that they aim to reach as much of the population as possible, TV Rain is a 'narrowcaster', providing content for a specific demographic of subscribers. Even when more widely available, its audience was disproportionately young and welleducated. ${ }^{43}$ Surveys since it became a subscriber service show that its audience is more liberal and open to criticising the regime than the average citizen. ${ }^{44}$

${ }^{42}$ Castells, 2009.

43 'Telekanal Dozhd' i sait tvrain.ru', TV Rain, 2013

<http://tvrain.ru/media/upload/files/tvrain web 2013.pdf>.

${ }^{44}$ Volkov and Goncharov, 2017. 


\section{Methodology}

The strategic narrative framework which structures this study allows for a range of methodologies, with most of the existing studies using various forms of qualitative analysis. Miskimmon et al. defend their framework against accusations of being unquantifiable, cautioning against dismissing qualitative methods which focus on language as unscientific. They suggest a range of methods are appropriate to study strategic narratives, with the only proviso being that methodology be transparent and systematic, in order to allow other scholars to evaluate the work.

For this study, thematic analysis, as set out by Braun and Clarke, was used to interpret the data. ${ }^{45}$ News reports were analysed to identify themes, which were taken as the building blocks of the overall strategic narrative. Identifying themes has been a widely used form of qualitative analysis across many fields. Braun and Clarke's framework is a welcome contribution in that it provides a rigorous structure to the process of identifying themes, thus defending the method against suspicions of 'anecdotalism'. ${ }^{46}$ While these researchers work in the field of psychology, they consider their method applicable across many other fields of qualitative research. As Braun and Clarke point out, there is no fixed 'cut-off point' to determine what is and is not a theme. ${ }^{47}$ Themes were identified as much based on their relevance to the research question as their quantifiable prevalence.

Analysis of textual extracts was conducted with the use of Nvivo software. Initial themes were conceived during data collection and refined in subsequent rounds of coding. Extracts from Channel One and TV Rain were constantly analysed and compared during coding to develop understanding of the two channels' differing approaches. In this sense, analysis was an inductive, 'grounded' process with codes developed and refined throughout analysis rather than being selected a priori. Video footage was viewed alongside the textual extracts to gain an understanding of how both the images and music chosen contributed to conveying a theme.

Coding was carried out by a single researcher, and as such the positionality of the researcher, as a non-Russian European, should be acknowledged. Interpreting media, as other scholars have found, is 'a complex navigation between broadcaster-generated and researcher-generated meanings' and therefore vulnerable to charges of inconsistency. ${ }^{48}$ The researcher has attempted to mitigate this by following a structured analytical approach as outlined above. It may further be noted that strategic narratives are understood as attempts to influence or persuade an imagined audience. Their importance is thus not only in themselves, but in the potential reaction of a viewer. During analysis, the

\footnotetext{
45 Virginia Braun and Victoria Clarke, 'Using thematic analysis in psychology', Qualitative Research in Psychology, 3.2, (2006), pp. 77-101.

46 Bryman, Alan, Quantity and quality in social research (London: Unwin Hyman, 1988), cited in Braun and

Clarke, p. 95.

47 Ibid, p. 82.

48 Hutchings and Tolz, p. 44.
} 
researcher takes on the role of the viewer, and the researcher's interpretations are one possible reaction of the audience. 


\section{Data collection}

Data was gathered from Channel One's website www.1tv.ru and the TV Rain website tvrain.ru. Data was identified using the search functions on these websites, with the search period delimited from 1 April 2015 to 1 April 2016 to include the most acute period of the refugee crisis, as well as the period of most extensive media coverage. The keywords used were 'migrant' (мигрант), 'refugee' (беженец), 'immigrant' (иммигрант), 'migration' (миграция), and 'immigration' (иммиграция). The wildcard search function was used to account for noun declensions (i.e., searching for иммиграц\% would return results for иммиграция, иммиграцию, иммиграции еtc.).

The intention was to gather reporting on the European refugee crisis. Results which contained those keywords, but were unrelated to the topic were therefore excluded.

\section{Channel One}

Reports were collected from the channel's flagship news show, Vremia (Time). Data gathering returned 609 results, of which 108 were text-only and 501 were video clips. The average length of the videos was 2:26 minutes (totalling over 17 hours of analysed video material). On Channel One's website, videos are accompanied by a transcript of their contents which was used for analysis. While this did not always reflect exactly what was said in the videos, this study follows Rozenas and Stukal in assuming that such transcripts are, if somewhat distorted, an unbiased representation of the report's content. Overall, the Channel One dataset included 187,512 words of news covering the refugee crisis.

\section{TV Rain}

Results from the TV Rain website included Novosti text-only news bulletins; extracts from Zdes'i seichas (Here and Now), TV Rain's live news show; and other news reports in video format, which did not form part of TV Rain's scheduled output. Data collection returned 181 stories, of which 132 were text-only and 48 contained video. The average length of the videos was 7:48 minutes (totalling over 6 hours of analysed video material). Some videos on the TV Rain website were accompanied by transcripts, although not all. Where available, the website's own transcript was used for analysis, and where absent, transcripts were produced by the researcher. The TV Rain dataset resulted in 76,347 words of reporting on the refugee crisis. 


\section{Findings and Analysis}

This section presents the findings from analysis of 609 Channel One news reports, and 181 TV Rain pieces. The structure of this section is dictated by the themes identified from data analysis, foregrounding those which were central to the projection of Channel One's strategic narrative, and discussing the dissenting approach to them taken by TV Rain.

\section{The cause of the crisis}

Along with much European and world media, coverage of the refugee crisis on Channel One and TV Rain initially focussed on the numerous shipwrecks in the Mediterranean in Spring 2015, later shifting to chaotic scenes at borders on the 'Balkan route'. As the story unfolded, the question repeatedly arose: why had migration suddenly increased? Channel One's narrative on this point was clear: they argued that mass migration had been caused by destabilising North Africa and the Middle East in the Arab Spring, a form of 'colour revolution' for which the West was responsible. The removal of Qaddafi in Libya and arming Syrian rebel groups were cited as specific examples of disastrous US policies in which European countries had been complicit. This narrative appeared on TV Rain only when reporting statements from Russian officials which reflected this account. Thus a typical Channel One report explained:

'Why did such a mass exodus to Europe not occur earlier? [...] blame lies on those politicians who, against the interests of their own countries, supported the USA in removing regimes in Africa and the Middle East by force. The Europeans have shot themselves in the foot. ${ }^{49}$

There was little sympathy for the Western European nations whom Channel One deemed responsible for their own misfortune, although a case was made for those nations which had opposed involvement in Libya and the Middle East. Channel One reserved further condemnation for the USA, which supposedly bore most responsibility but avoided the consequences.

'This year the USA will take a mere 1,000 - 2,000 refugees from Syria. The Europeans will have to deal with the consequences of invading Iraq, bombing Libya, and military assistance for Syrian insurgents by themselves. ${ }^{150}$

Previous studies of strategic narratives on Russian state television have noted how the USA and Europe are differentiated within the concept of 'The West' with anti-Americanism ubiquitous, but Europe presented as having been led astray by malign US influence. ${ }^{51}$ The narrative found during the refugee crisis went further in that it pits the USA and Europe against each other, suggesting that Europe has been betrayed by its erstwhile ally.

${ }^{49}$ Vremia, 28/08/2015.

50 Vremia, 26/08/2015.

51 Szostek, 2017. 


\section{Europe: a safe haven?}

After long and arduous journeys, what awaited refugees in their new European homes? Channel One repeatedly emphasised that refugees' expectations were outsized and that the squalid reality they faced could not help but disappoint, even suggesting they would prefer to return home. TV Rain, too, described the 'immigrant's dream' of Europe as 'some fairy-tale country. ${ }^{52}$ However, unlike Channel One, the conviction that their hopes would be miserably disappointed was absent.

On Channel One, the narrative of disillusionment and unfulfilled promises was linked to the supposed pervasive hypocrisy of European politics, contrasting an initial welcome with subsequent measures to limit refugee numbers to imply that European countries misled those wishing to settle there. Hypocrisy was particularly emphasised following the March 2016 deal struck between the EU and Turkey, which would see all migrants arriving in Greece who were not in need of international protection returned to Turkey, and which greatly reduced the numbers arriving. ${ }^{53}$ It should be borne in mind that at this time, Russia's relations with Turkey were at a low point after Turkey had shot down a Russian fighter plane accused of violating its airspace, and Russia responded with sweeping economic sanctions. ${ }^{54}$ Channel One's coverage was correspondingly unflattering to Turkey, with a series of reports detailing human rights abuses against the Kurdish people. The deal with Turkey was therefore presented as a hypocritical betrayal of the human rights the EU claimed to defend.

'So the Turkish President will carry out all the dirty work, not letting refugees into Europe, and help Merkel inside Germany itself to escape the impact, and retain the appearance of the open doors policy, while in fact locking migrants inside Turkey. ${ }^{.55}$

Indeed, human rights on Channel One were largely presented as an example of Europe's hypocrisy, suggesting these ideals were weaponised to attack other countries while not being upheld at home. Human rights were not referenced this way on TV Rain, which carried out numerous interviews with representatives of human rights organisations during the period and, while noting that conditions for refugees moving across Europe were at times extremely poor, referenced human rights without accusations of hypocrisy.

At times Channel One's coverage showed sympathy for the refugees' plight, most noticeably in accounts of the incompetence, bordering on cruelty, of European authorities.

\footnotetext{
52 Zdes'i seichas, 29/08/2015.

53 'Statement of the EU Heads of State or Government, 07/03/2016', European Council, 8 March 2016 <https://www.consilium.europa.eu/en/press/press-releases/2016/03/08/eu-turkey-meeting-statement/>; Neske Baerwaldt, 'The European Refugee Crisis: Crisis for Whom?' Border Criminologies, 20 March 2018. <https://www.law.ox.ac.uk/research-subject-groups/centre-criminology/centrebordercriminologies/blog/2018/03/european-refugees

54 Etienne Henry, 'The Sukhoi Su-24 incident between Russia and Turkey', Russian Law Journal, 4 (2016), pp. $8-25$

55 Vremia, 20/03/2016.
} 
Thus one report described housing for refugees marked with red doors, coyly concluding 'Now every passer-by knows: in this apartment lives a foreigner [чужак]. [...] The authorities prefer not to think about the unpleasant associations. ${ }^{156}$ On screen, images of the red doors were intercut with footage of the Star of David daubed on Jewish properties in 1930s Germany to the sound of ominous music.

The host population in Europe was also shown to be far from welcoming to refugees. Channel One's reporting implied that an influx of people from another culture would inevitably inflame xenophobic sentiments in the host population. The rise of far-right, Islamophobic, and neo-Nazi movements was frequently discussed, as well as in-depth coverage of the success of the Front National in 2015 regional elections in France, and March 2016 state elections in Germany which saw a rise in popularity of the Alternative für Deutschland (AfD) party. Channel One attributed these shifts in electoral fortunes wholly to the impact of the refugee crisis, while TV Rain's analysis identified other contributing factors such as the economic circumstances and the terrorist attacks carried out by IS in Paris. Channel One also frequently covered violent confrontations between far-right and left-wing protestors, stressing social disruption rather than a political agenda and focussing on the breakdown of law and order.

At times, TV Rain's reporting of far-right demonstrations resembled Channel One's, in that it focussed on disorder, arrests, and property damage. However, some of their analysis offered a more nuanced picture:

'It must be said that German right-wing extremists and neo-Nazis are already trying to use this story [allegations of crime perpetrated by migrants] in their interests. ${ }^{157}$

Such reporting suggests that this phenomenon had not arisen naturally but was politically motivated. Rather than framing social tension as an inevitable consequence of the refugee crisis, TV Rain indicated that these events could be exploited to suit the agenda of certain political groups.

\section{The failure of multiculturalism in Europe}

At times Channel One also purported to adopt the perspective of the host population, depicting refugees as a problem for their new cities, not least because of their perceived failure to integrate. Previous studies of state-controlled television have noted how interethnic strife in Europe's multicultural states is contrasted with harmonious multinationalism in Russia in official Russian reporting. ${ }^{58}$ The failure of multiculturalism in Europe in the wake of the refugee crisis was discussed at length on Channel One. This vision of Europe sees migrants consigned to ghettos on the outskirts of European cities,

\footnotetext{
56 Vremia, 24/01/2016.

57 Zdes' i seichas. Vechernee shou, 20/01/2016.

58 Hutchings and Tolz, p. 54; Vera Tolz, 'From a threatening "Muslim migrant" back to the conspiring "West:" race, religion, and nationhood on Russian television during Putin's third presidency', Nationalities Papers, 45.5 (2017), pp. 742-757.
} 
supposedly no-go zones for European citizens and law-enforcement and associated with high levels of crime. Introducing a report titled 'Metastasis', the newsreader declared:

'The districts which were considered the melting pot of nations [...] have turned into dangerous tumours. ${ }^{159}$

This metaphor paints multi-ethnic communities as a malignant disease within the nation, threatening its destruction. In Channel One's narrative this is partly the fault of migrants who refuse to adapt, and partly the fault of authorities who fail to adequately manage the integration process. Europe is seen as too accommodating to new arrivals, changing European customs rather than imposing assimilation.

'The story of baby Jesus and the holy festival of the Birth of Christ to the rhythmic movement of thighs and music from Tarkan [a German-Turkish musician] songs. [...] If you wanted to draw some conclusions from this year, then here they are in these few minutes. And if you remember also that Christmas markets were renamed as amorphous and tolerant "winter" markets and that there were calls for [German Chancellor] Angela Merkel to record the New Year address to the nation with Arabic subtitles, the picture will be almost complete. ${ }^{160}$

Religion was cited frequently on Channel One as one of the factors hindering integration. Channel One criticised European cultures - at times equated with Christian, as in the extract above - for failing to defend themselves against Islamic culture, reporting on shops no longer selling pork, and schools where short skirts were banned for fear of offending Muslims. Reportage from so-called migrant ghettos lingered on women in hijabs, and bearded men with taqiyah caps, visually identifying them as Muslim; and featured shops selling prayer mats and Arabic-language CDs. This narrative suggested that a Muslim way of life is incompatible with assimilation.

Channel One thus framed Europe's attempt at multiculturalism as a failure, leading to segregated communities and ethnic and religious tension. This was explicitly contrasted with Russia's approach. In a report on lessons Russia could learn from the European refugee crisis, the channel summarised a Security Council discussion:

'Russia remains open to everyone who is prepared to live and work here honestly. At the same time it's not worth coming to our country with, as they say, your own ways. Respect for the Russian language, culture, traditions and laws is an obligatory requirement for any newcomer. ${ }^{61}$

Following the terrorist attacks carried out by IS militants in Paris in November 2015, and in Brussels in March 2016, TV Rain too reported on migrant ghettos where Islamic radicalisation was judged likely. Much of Channel One's narrative was repeated here:

${ }^{59}$ Vremia, 27/03/2016.

60 Vremia, 27/12/2015.

61 Vremia, 31/03/2016. 
districts where law-enforcement would not enter, high levels of crime, and a population defined by their religion. The insistence on the failure of multiculturalism did not occur outside of this context.

Interestingly, TV Rain also reversed the narrative in a series of reports on Berlin's Russianspeaking community in February 2016. These stories reflected the tropes used on state channels to illustrate the failure of integration, even examining the possibility that residents could be manipulated by Russian television to undermine the German state. Just as Channel One reportage had focussed on hijabs and Arabic-language CDs for sale, TV Rain's camera runs over Russian-language posters and shop signs:

'A restaurant named Shashlik, and the sounds of a Russian singer from the doors of the "Mayak" shop. This is Marzahn, a district of Berlin where you barely hear German on the streets. ${ }^{\prime 62}$

Echoing the fears that radical Islam would spread in European ghettos, TV Rain reports:

'Russian speakers who do not manage to integrate in Germany often join radical right-wing groups. ${ }^{163}$

Ultimately, though, TV Rain's message is about the success of integration.

'Dissatisfaction with the "open doors" policy really is growing in Germany and the coincidence in this opinion of Germans and Russian-speaking residents [...] speaks rather to the fact that immigrants sooner or later do integrate. [...] those who are arriving in the country now will in future most likely consider themselves Germans and be upset about new waves of immigration. ${ }^{64}$

It is striking how closely these reports echo the structure and tropes of Channel One pieces reporting on immigrants in European ghettos. The TV Rain series, however, radically reverses the dynamic by casting Russian-speakers themselves as the potentially subversive, foreign element within the German state.

\section{Crime, sexual harassment, and cover-ups}

Channel One frequently reported on individual crimes committed by refugees, from petty theft to murder, and directly attributed rising crime to the influx of immigrants. The viewer was asked to sympathise with European citizens who were presented as living in fear. In particular, the fear European women supposedly felt around refugees was highlighted. Channel One's reporting intimated that because of their non-European cultural background, refugees were more likely to commit sexual harassment or violence.

\footnotetext{
62 Spetsial'nyi proekt, 21/02/2016.

63 Ibid.

64 Ibid.
} 
'“[...migrants] are raping little girls, children. [...]” says one resident. Women are frightened.' 65

The assertion that migrants from the Middle East and North Africa posed a threat to European women played into long-standing racist tropes which posit men of colour as a danger to white women. This bears great similarity to the damaging stereotype noted in previous studies of European media reporting on Muslim migrants, which connect the modern tendency to 'Orientalist and Western colonial imagery of coloured men as sexual predators'. ${ }^{66}$ This theme became particularly prominent following New Year's Eve 2016 when hundreds of sexual assaults and thefts were reported in Cologne. The majority of suspects were from North Africa and the Middle East, according to the German Chief Prosecutor. Like Channel One, TV Rain reported extensively on the Cologne incident and subsequent demonstrations protesting sexual violence. Excluding the Liza case (discussed below), no other cases linking refugees or migrants to sexual violence appeared on TV Rain.

Both channels noted that police had not reported the Cologne attacks for several days after New Year. On Channel One, this corroborated a regular allegation that European authorities concealed crimes committed by refugees or offered them preferential treatment. Numerous stories depicted police refusing to investigate or record crimes perpetrated by refugees, courts handing down lighter sentences, or the media not reporting such crimes. Overall, this created the impression that authorities were unwilling to protect their populations against rising crime and harassment, establishing a lack of trust in official statements. The refusal to countenance criticism of refugees, in Channel One's version, extended from seats of authority throughout society, where a 'conspiracy of silence ${ }^{67}$ prevented people from speaking out for fear of being accused of racism. On TV Rain, this narrative was mentioned in connection with the Cologne incident and the Liza case but was otherwise not present.

\section{The Liza Case: Reflections on the interactions between Russian media}

The themes and tropes discussed above bear similarities to coverage of the refugee crisis in European media, as studies of the European press have shown. ${ }^{68}$ There was, however,

\footnotetext{
65 Vremia, 16/01/2016.

66 Iris Wigger, 'Anti-Muslim racism and the racialisation of sexual violence: 'intersectional stereotyping' in mass media representations of male Muslim migrants in Germany,' Culture and Religion, 20.3 (2019), 248271, p. 258; Miriam Ticktin, 'Sexual Violence as the Language of Border Control: Where French Feminist and Anti-immigrant Rhetoric Meet', Signs: Journal of Women in Culture and Society, 33.4 (2008), pp. 863-889. 67 Vremia, 31/01/2016.

68 Mike Berry, Inaki Garcia-Blanco, and Kerry Moore, Press Coverage of the Refugee and Migrant Crisis in the EU: An Analysis of Five European Countries (Report prepared for the United Nations High Commission for Refugees, 2015); (Berry et al., 2015; Images of immigrants and refugees in Western Europe : media representations, public opinion and refugees' experiences, ed. by d'Haenens, Leen, Joris, Willem and Heinderyckx, François, (Leuven : Leuven University Press, 2019); Jakob-Moritz d'Haenens et al., 2019; Eberl, Christine Meltzer, Tobias Heidenreich, Beatrice Herrero, Nora Theorin, Fabienne Lind, Rosa Berganza, Hajo Boomgaarden, Christian Schemer, and Jesper Strömbäck, 'The European media discourse on immigration and its effects: a literature review', Annals of the International Communication Association, 42.3 (2018), pp.207-223.; Eberl et al., 2018)
} 
one story that was not found in European news cables but was covered extensively in Russia. The case of a 13-year-old from Berlin's Russian community, identified only as Liza F., who was allegedly kidnapped and raped by a group of migrants first appeared on Channel One on 16 January 2016. It soon escalated from television news to spark protests among Russian-speaking Germans against perceived police inaction and an investigation into the correspondent behind the original report on suspicion of inciting ethnic hatred. Later that month, when asked in a press conference about German-Russian relations, Russian Foreign Minister Sergei Lavrov accused German authorities of sweeping the case of 'our Liza' under the carpet, sparking a diplomatic dispute. ${ }^{69}$ However, German police had rapidly established that no crime had been committed. This was never given credence on Channel One.

The resonance of the Liza story on Channel One can in part be attributed to the fact that it drew on themes well-seeded throughout coverage of the refugee crisis: crime and the threat of sexual violence, fear amidst the host population, lack of protection from law enforcement, and unwillingness to speak out against criminal migrants. Distrust of German authorities gave the channel a pretext to discredit official statements asserting that no crime had been committed.

TV Rain, on the other hand, reported early on that police had found no evidence of a crime and subsequently always qualified mention of the allegations: 'the Russian girl supposedly [якобы] raped by migrants ${ }^{10}$. Thereafter, the case was used to examine the behaviour of state-controlled media, its influence in Germany, and the role of stories about migrants in its reporting.

TV Rain's coverage suggested that state-controlled television was using its influence over the Russo-German community to sow discord. Thus they interviewed members of this community about their television-watching habits, finding they trusted Russian channels over German news. While Channel One dismissed Martin Luithle, the lawyer who had called for an investigation against their correspondent, TV Rain interviewed him to discuss how state television had been instrumentalised in this case. TV Rain also carefully debunked false or exaggerated claims made in the Channel One stories. These reports conclude that:

'The theme of anti-immigrant sentiment in Germany has been actively supported by Russian media. ${ }^{71}$

TV Rain's investigations asserted that the Liza case fit a broader pattern of scare stories about migrants in Europe. They even ran a spoof investigation entitled 'An instruction manual: how to shoot exposés for a federal channel', in which they identified a woman who had recently appeared on a state-owned channel to discuss her plans to return to Russia from Germany because of the 'outrages'72 committed by migrants. In fact, she was a freelance producer for state-controlled channels with no plans to leave Germany.

\footnotetext{
69 Nikolai Klimeniouk, 'How “Operation Liza” failed', OpenDemocracy, 9 February 2016

<https://www.opendemocracy.net/en/odr/how-operation-liza-failed/>.

70 Spetsial'nyi proekt, 21/02/2016.

71 Zdes' i seichas. Vechernee shou, 20/01/2016.

72 Bremia novostei, 31/01/2016.
} 
“"Channel One paid me 500 as well. REN-TV paid 300. Then there was Rossiia-1, live, I worked with them too, they're also making [reports] about migrants. Basically, everyone's making [reports] about migrants."

[...] We pay 500 roubles and make our way to Germany. Now let's talk about the invasion of migrants into Europe.

[TV Rain reporter:] "You should play the role [...] you say you've had enough of them: all these Tunisians, Syrians."

"Syrians, negritos, who are constantly harassing our women, I'm very afraid for my wife, for my daughter." 73

TV Rain thus picks up on central themes to Channel One's alarmist reporting, while also undermining the legitimacy of their methods.

73 Ibid. 


\section{Discussion}

\section{The political intent behind strategic narratives}

Analysis of Channel One's news reporting on the European refugee crisis thus demonstrates a clear strategic narrative. This vision of Europe was extremely negative, framing the refugee crisis as a catastrophe from which European institutions, politics, and society could not recover. There were contradictions within this narrative, which at times sympathised with refugees in the face of the authorities' incompetence, while elsewhere suggesting authorities were complicit in covering up refugees' criminal behaviour; but the consistent unifying thread was vilification of the situation in Europe. Recent studies of strategic narratives on state-controlled television found that, as diplomatic relations between Russia and the West worsened, coverage of the West became correspondingly harsher. ${ }^{74}$ Szostek's findings from June-July 2014 suggested that attitudes towards Europe were more favourable than towards the USA precisely because Russia still hoped to engage the EU and preserve cooperation. The period covered by this research represents a phase of more hostile relations between the EU and Russia as the former maintained economic sanctions in response to the annexation of Crimea.

Indeed, the narrative found on Channel One corresponded closely to official statements, including those made by such high-ranking officials as the President and Foreign Minister. Examining remarks made by President Putin at a March 2016 Security Council meeting, for example, many of the central themes from Channel One's coverage can be found:

'We see what serious consequences the practically uncontrolled flows of refugees to Europe from countries of the Middle East, North Africa, from Afghanistan and other regions have led to. Here there is also a spike in crime, and conflicts on national and religious grounds, and social tension. Migrants, who are effectively denied any opportunity to integrate into society, become the object of propaganda and recruitment by extremists and terrorist organisations. [...] radical sentiments also grow among local citizens. ${ }^{.75}$

The themes of crime, social division, the failure of integration, radicalisation, and increasing far-right extremism, so prevalent in the Channel One reports studied, are all directly linked to the arrival of refugees by the occupant of Russia's highest office. Equally, the narrative thread which blamed the crisis on US policies and Europe's complicity reflects statements from leading foreign policy makers at the time. Thus in a September 2015 press conference Putin analysed the refugee crisis as follows:

'I think this is an absolutely predictable crisis [...]. This is above all, of course, the policy [of involvement in the Middle East and North Africa] of our American partners. Europe blindly follows this policy [...] then itself has to bear the burden. ${ }^{76}$

\footnotetext{
74 Szostek, 2017; Makukhin et al, 2018.

75 'Zasedanie Soveta Bezopasnosti', Kremlin, 31 March 2016

<http://www.kremlin.ru/events/president/news/51618>

76 'Vladimir Putin otvetil na voprosy rossiiskikh zhurnalistov', Kremlin, 4 September 2015

<http://www.kremlin.ru/events/president/news/50234>.
} 
The direction of the strategic narrative at the time of the refugee crisis may thus be interpreted as a reflection of the administration's foreign policy at the time, which was hostile to the EU and to the West as a whole.

In contrast to this narrative of dysfunctional and divided Europe, Russia could be held up as a model of effective and pragmatic governance. The depiction of a breakdown in law and order in Europe - ineffective border control, the supposed crime wave, and the clashes between rival protest groups - could be read as a contrast to the vaunted stability of Russia under the Putin regime. This depiction of Russia as superior to Europe fits into a broader narrative projected by Putin throughout his presidencies, that of Russia 'rising from its knees'. ${ }^{77}$ As Neumann has outlined, for centuries Russian national identity struggled with a perception of being 'behind' in relation to a more 'developed' Europe. ${ }^{78}$ Criticism of Europe and the elevation of Russia in comparison should therefore be understood as a projection of a proud national identity. As Neumann has argued, 'the Russian debate about Europe is a debate about what Russia itself should be'. ${ }^{79}$ Channel One's critique that Europe's liberal values have been distorted - by political hypocrisy which shows no genuine regard for human rights, by excess of political correctness blinding authorities to refugees' supposed criminality - could in fact be interpreted as defending Russia's rejection of those values and embrace of so-called 'traditional values'. Virulent criticism of Europe should therefore be seen in the context of the 'conservative turn' domestically in Putin's third presidential term, ${ }^{80}$ as well as the international context of hostility towards the EU. It may even be related to the discourse of Russian messianism identified by Duncan, in that Russia is depicted on the true path while Europe has gone wayward: Europe may right itself by following the Russian model. ${ }^{81}$ Braghiroli and Makarychev recognise this tendency in Russia's policies towards Europe (and particularly European nationalist groups) during the refugee crisis, finding that Moscow's attempts to oppose the EU's liberal cosmopolitanism were a strategy to redefine Europe in more conservative terms and thus mitigate Russia's political isolation from Europe.

\section{Independent media as the watchdog of state-controlled media}

TV Rain did not so much put forward its own strategic narrative as offer a corrective to that of the state-controlled channel. The second major finding of this study is to understand the tactics TV Rain used to challenge the dominant strategic narrative. As the results of this

\footnotetext{
77 Oleg Riabov and Tatiana Riabova, 'The Remasculinization of Russia?: Gender, nationalism and the legitimation of power under Vladimir Putin', Problems of Post-Communism, 61.2 (2014), pp. 23-35.

78 Iver Neumann, Russia and the idea of Europe: a study in identity and international relations (London, New York: Routledge, 1996).

79 Iver Neumann, 'Russia's Europe, 1991-2016: inferiority to superiority', International Affairs, 92.6 (2016), 1381-1399, p. 1395. I

80 Marlène Laruelle, 'Conservatism as the Kremlin's New Toolkit: an Ideology at the Lowest Cost', Russian Analytical Digest, 138 (2013), 2-4; Andrei Tsygankov, 'Crafting the State-Civilization Vladimir Putin's Turn to Distinct Values', Problems of post-communism, 63.3 (2016), pp. 146-158.

81 Duncan, Peter, Russian messianism: third Rome, revolution, communism and after, (London: Routledge, 2000).
} 
research show, TV Rain's reporting diverged from that of Channel One on numerous points. More than just covering events differently, however, TV Rain actively engaged with Channel One and other state-controlled broadcasters to challenge the narrative they disseminated. This suggests that TV Rain interprets its role as an independent media outlet to involve not only maintaining an independent editorial line, but acting as a watchdog for statecontrolled channels.

The findings of this study indicate that TV Rain employs several different tactics in order to challenge Channel One's strategic narrative. The following typology is proposed to describe how independent media respond to mainstream reporting in state-controlled media as an emerging backbone to a new theory explaining how independent media interact with state media in regimes where media freedom is compromised. This typology embraces the following media strategies:

- Ignore. Some themes prevalent on Channel One were not found on TV Rain, which refused to amplify such frames. This was true of Channel One's explanation of the cause of crisis, for example.

- Limit. At times TV Rain reported a specific story in a similar manner to Channel One, but did not extrapolate from a single case into a broader trend. Thus, coverage of the Cologne attacks was similar, but unlike Channel One, TV Rain did not indicate this was a widespread problem. Similarly, TV Rain reported on supposed migrant ghettos following terrorist attacks in November 2015 and March 2016, but did not broaden these stories into an assertion that multiculturalism had failed in Europe.

- Fact-check. In certain cases, TV Rain directly challenged information provided by Channel One. For example, in the Liza case, TV Rain amplified the version of events given by German police, denying the allegations reported on Channel One.

- Delegitimise. By investigating state-controlled channels' reporting practices, TV Rain worked to discredit their journalism, for example by exposing their practice of paying actors to take on roles espousing specific viewpoints.

- Cover. Crucially, TV Rain included coverage of state-controlled channels' behaviour within its journalistic remit. Where it observed systematic use of media for a particular outcome - as when reporting on the Liza case was used to mobilise Germany's Russian-speaking community - this tendency itself became a story.

The importance of journalism - the Fourth Estate - has typically been conceptualised in terms of its ability to hold government to account, to act as a watchdog to power. ${ }^{82}$ This essential democratic function can best be fulfilled when independent from the state. ${ }^{83}$ However, the findings of this study suggest that in TV Rain's case, the watchdog role relates not only to the political regime, but also as a check on state-controlled media itself. TV Rain acknowledges the power and influence mass media can have and the remit of their reporting includes holding Channel One to account. In an age increasingly defined as 'post-

\footnotetext{
82 Julianne Schultz, Reviving the Fourth Estate: Democracy, Accountability and the Media, (Cambridge: Cambridge University Press, 1998); Beth Knobel, The Watchdog Still Barks: How Accountability Reporting Evolved for the Digital Age, (New York: Fordham University Press, 2018).

83 W. Lance Bennett, 'The press, power and public accountability', in The Routledge companion to news and journalism, ed. by Stuart Allan (London: Routledge, 2010), pp. 105-115.
} 
Truth' and understood in terms of 'fake news', ${ }^{84}$ the potential of media outlets to fact-check and correct not only politicians and public figures, but also other media outlets, deserves further exploration.

84 Johan Farkas and Jannick Schou, Post-truth, fake news and democracy: mapping the politics of democracy (New York: Routledge, 2020). 


\section{Conclusion}

This article has shown how a strategic narrative was developed on Channel One around the refugee crisis, presenting a vision of Europe in crisis and on the edge of collapse. The political intent of state-controlled media, however, was challenged in the reporting of TV Rain, which used various strategies to hold state-controlled media to account.

It is a limitation of this study that only one independent outlet was examined; and, one might add, a limitation of the Russian media landscape that only one independent national television channel survives. Further research should examine a broader range of media outlets. Furthermore, it was not within the scope of this study to encompass other forms of media such as independent newspapers or news websites, or journalists' YouTube channels. Further research could investigate whether the example of TV Rain is generalisable to other independent media in Russia; or indeed whether the findings of research in the Russian context are applicable to other countries where independent media compete with state-controlled outlets in conditions where media freedom is compromised.

This study thus contributes to the developing body of literature exploring strategic narratives in Russian media. By examining Channel One coverage of the European refugee crisis, it reveals the troubled story told of a struggling Europe - and the image of a stable, well-governed Russia which emerges in contrast. This supports previous studies of strategic narratives in Russian media while providing in-depth detail about a period not previously researched in this light. It also breaks new ground by investigating how independent media respond to a prevalent strategic narrative. As this study shows, TV Rain challenged the dominant narrative not only by reporting differently, but by acting as a watchdog on Channel One's coverage. Thus at times they corrected false information and exposed unprofessional journalistic practices, thereby seeking to discredit the information provided by the state-controlled channels. As far as this researcher is aware, this function has not been identified in existing research on the role of independent media. It would be interesting to take this study further and qualitatively 'test' these findings in other politically hybrid regimes with marginalised but nevertheless influential independent media. 


\section{Bibliography}

\section{All translations are the author's own.}

Baerwaldt, Neske, 'The European Refugee Crisis: Crisis for Whom?' Border Criminologies, 20 March 2018. <https://www.law.ox.ac.uk/research-subject-groups/centrecriminology/centreborder-criminologies/blog/2018/03/european-refugee>

Bennett, W. Lance, 'The press, power and public accountability', in The Routledge companion to news and journalism, ed. by Stuart Allan (London : Routledge, 2010), 105-115.

Berry, Mike, Garcia-Blanco, Inaki and Moore, Kerry, Press Coverage of the Refugee and Migrant Crisis in the EU: An Analysis of Five European Countries (Report prepared for the United Nations High Commission for Refugees, 2015)

Braghiroli, Stefano and Makarychev, Andrey, 'Redefining Europe: Russia and the 2015 Refugee Crisis', Geopolitics, 23.4 (2018), 823-848

Braun, Virginia and Clarke, Victoria, 'Using thematic analysis in psychology', Qualitative Research in Psychology, 3.2, (2006), 77-101

Bryman, Alan, Quantity and quality in social research (London: Unwin Hyman, 1988)

Castells, Manuel, Communication power (Oxford, New York: Oxford University Press, 2009)

'Doverie SMI i tsenzura', Levada-tsentr, 18 November 2016 <https://www.levada.ru/2016/11/18/doverie-smi-i-tsenzura>

Duncan, Peter, Russian messianism : third Rome, revolution, communism and after, (London: Routledge, 2000)

Eberl, Jakob-Moritz, Meltzer, Christine, Heidenreich, Tobias, Herrero, Beatrice, Theorin, Nora, Lind, Fabienne, Berganza, Rosa, Boomgaarden, Hajo, Schemer, Christian and Strömbäck, Jesper, 'The European media discourse on immigration and its effects: a literature review', Annals of the International Communication Association, 42.3 (2018), 207223

Farkas, Johan and Schou, Jannick, Post-truth, fake news and democracy: mapping the politics of democracy (New York: Routledge, 2020)

Forging the world: strategic narratives and international relations, ed. by Miskimmon, Alister, O'Loughlin, Ben and Roselle, Laura (Ann Arbor : University of Michigan Press, 2017)

Goncharov, Stepan, 'The Whys and Wherefores of Russians' Trust in their Media', Riddle, 27 June 2019 <https://www.ridl.io/en/the-whys-and-wherefores-of-russians-trust-in-theirmedia> 
Greene, Samuel, and Robertson, Graeme, Putin v. the people: the perilous politics of a divided Russia (New Haven: Yale University Press, 2019)

Henry, Etienne, 'The Sukhoi Su-24 incident between Russia and Turkey', Russian Law Journal, 4 (2016) 8-25

Hinck, Robert, Cooley, Skye and Kluver, Randolph, Global Media and Strategic Narratives of Contested Democracy: Chinese, Russian, and Arabic Media Narratives of the US Presidential Election, (London: Routledge, 2019)

Hinck, Robert, Kluver, Randolph and Cooley, Skye, 'Russia re-envisions the world: strategic narratives in Russian broadcast and news media during 2015', Russian Journal of Communication, 10.1 (2018), 21-37

Hutchings, Stephen and Tolz, Vera, Nation, ethnicity and race on Russian television: mediating post-Soviet difference, (London : Routledge, 2015)

Images of immigrants and refugees in Western Europe: media representations, public opinion and refugees' experiences, ed. by d'Haenens, Leen, Joris, Willem and Heinderyckx, François, (Leuven : Leuven University Press, 2019)

Kazun, Anastasia, 'Framing sanctions in the Russian media: the rally effect and Putin's enduring popularity', Demokratizatsiya, 24.3 (2016), 327-50

Klimeniouk, Nikolai, 'How "Operation Liza” failed', OpenDemocracy, 9 February 2016 <https://www.opendemocracy.net/en/odr/how-operation-liza-failed/>

Knobel, Beth, The Watchdog Still Barks: How Accountability Reporting Evolved for the Digital Age, (New York: Fordham University Press, 2018)

Lankina, Tomila and Watanabe, Kohei, "Russian Spring' or 'Spring Betrayal'? The Media as a Mirror of Putin's Evolving Strategy in Ukraine', Europe-Asia Studies, 69.10 (2017), 15261556

Laruelle, Marlène, 'Conservatism as the Kremlin's New Toolkit: an Ideology at the Lowest Cost', Russian Analytical Digest, 138 (2013), 2-4

Lipman, Maria, 'Independent Media Live on in Putin's Russia', Russian Analytical Digest, 197 (2017), 2-5

Makukhin, Oleksiy, Tsybulska, Liubov and Kavatsiuk, Ruslan, 'How Russian media foments hostility toward the West', Hybrid Warfare Analytical Group, September 2018 <https://uacrisis.org/wp-content/uploads/2018/02/TV-II-n.pdf> 
Miskimmon, Alister, O'Loughlin, Ben, and Roselle, Laura, Strategic narratives: communication power and the new world order (New York, London : Routledge, 2013)

'Ne slyshali pro «Dozhd'»', Levada-tsentr, 28 February 2014 <https://www.levada.ru/2014/02/28/ne-slyshali-pro-dozhd>

Neumann, Iver, Russia and the idea of Europe: a study in identity and international relations (London, New York: Routledge, 1996)

Neumann, Iver, 'Russia's Europe, 1991-2016: inferiority to superiority', International Affairs, 92.6 (2016), 1381-1399

Nye, Joseph, Bound to Lead: The Changing Nature of American Power (New York: Basic Books, 1990)

Nye, Joseph, Soft Power: The Means to Success in World Politics (New York: PublicAffairs, 2004)

Oates, Sarah, 'The neo-Soviet model of the media', Europe-Asia studies, 59.8 (2007), 12791297

Oates, Sarah and Steiner, Sean, 'Projecting Power: Understanding Russian Strategic Narrative', Russian Analytical Digest, 229 (2018), 2-5

Riabov, Oleg and Riabova, Tatiana, 'The Remasculinization of Russia?: Gender, nationalism and the legitimation of power under Vladimir Putin', Problems of Post-Communism, 61.2 (2014), 23-35

Roselle, Laura, 'Strategic Narratives and Great Power Identity', in Forging the world: strategic narratives and international relations ed. by Miskimmon, Alister, O'Loughlin, Ben and Roselle, Laura (Ann Arbor: University of Michigan Press, 2017), pp. 56-84

Roudakova, Natalia, Losing Pravda: Ethics and the Press in Post-truth Russia (Cambridge: Cambridge University Press, 2017)

Rozenas, Arturas and Stukal, Denis, 'How Autocrats Manipulate Economic News: Evidence from Russia's State-Controlled Television', The Journal of Politics, 81.3 (2019), 982-96

Schimpfossl, Elisabeth and Yablokov, Ilya, 'Coercion or Conformism? Censorship and SelfCensorship among Russian Media Personalities and Reporters in the 2010s', Demokratizatsiya: The Journal of Post-Soviet Democratization, 22.2 (2014), 295-311

Schultz, Julianne, Reviving the Fourth Estate: Democracy, Accountability and the Media, (Cambridge: Cambridge University Press, 1998) 
Sidorov, Dmitry, 'How Russian TV propaganda is made', Open Democracy, 25 August 2015 <https://www.opendemocracy.net/en/odr/how-russian-tv-propaganda-is-made>

'Statement of the EU Heads of State or Government, 07/03/2016', European Council, 8 March 2016 <https://www.consilium.europa.eu/en/press/press-releases/2016/03/08/euturkey-meeting-statement/>

Szostek, Joanna, 'Defence and Promotion of Desired State Identity in Russia's Strategic Narrative', Geopolitics, 22.3 (2017), 571-593

'Telekanal Dozhd' i sait tvrain.ru', TV Rain, 2013 <http://tvrain.ru/media/upload/files/tvrain web 2013.pdfs

Ticktin, Miriam, 'Sexual Violence as the Language of Border Control: Where French Feminist and Anti-immigrant Rhetoric Meet', Signs: Journal of Women in Culture and Society, 33.4 (2008), 863-889

Tolz, Vera, "From a threatening "Muslim migrant" back to the conspiring "West:" race, religion, and nationhood on Russian television during Putin's third presidency', Nationalities Papers, 45.5 (2017), 742-757

Trilling, Daniel, 'How the media contributed to the migrant crisis', Guardian, 1 August 2019 <https://www.theguardian.com/news/2019/aug/01/media-framed-migrant-crisis-

disaster-reporting>

Tsygankov, Andrei, 'Crafting the State-Civilization Vladimir Putin's Turn to Distinct Values', Problems of post-communism, 63.3 (2016), 146-158

'Vladimir Putin otvetil na voprosy rossiiskikh zhurnalistov', Kremlin, 4 September 2015 <http://www.kremlin.ru/events/president/news/50234>

Volkov, Denis and Goncharov, Stepan, 'Rossiiskii medialandshaft: osnovnye tendentsii ispol'zovaniia SMI - 2017', Levada-tsentr, 22 August 2017 <https://www.levada.ru/2017/08/22/16440>

Volkov, Denis and Goncharov, Stepan, 'Rossiiskii medialandshaft 2019: televidenie, pressa, internet i sotsial'nye seti', Levada-tsentr, 1 August 2019 <https://www.levada.ru/2019/08/01/21088>

Volkov, Denis and Goncharov, Stepan, 'Rossiiakii medialandshaft 2020', Levada-tsentr, 28 April 2020 <https://www.levada.ru/2020/04/28/rossijskij-medialandshaft-2020>

Walker, Christopher, Ludwig, Jessica, Cardenal, Juan Pablo, Kucharczyk, Jacek, Meseznikov, Grigorij, and Pleschova, Gabriela, 'Sharp Power: Rising Authoritarian Influence', National Endowment for Democracy, 5 December 2017 < https://www.ned.org/sharppower-rising-authoritarian-influence-forum-report/> 
Walker, Shaun, 'TV Rain: Inside Russia's only independent TV channel', Guardian, 9 June 2015 <https://www.theguardian.com/cities/2015/jun/09/tv-rain-russia-only-independenttelevision-channels

Wigger, Iris, 'Anti-Muslim racism and the racialisation of sexual violence: 'intersectional stereotyping' in mass media representations of male Muslim migrants in Germany,' Culture and Religion, 20.3 (2019), 248-271

Zakem, Vera, Saunders, Paul, Hashimova, Umida and Hammerberg, Kathleen, 'Mapping Russian Media Network: Media's Role in Russian Foreign Policy and Decision-making', CNA, January 2018 <https://www.cna.org/cna files/pdf/DRM-2017-U-015367-3Rev.pdf>

'Zasedanie Soveta Bezopasnosti', Kremlin, 31 March 2016 <http://www.kremlin.ru/events/president/news/51618> 